\title{
Vibrational Study of a Helicopter Tail Rotor Blade with Different Polymer Inner Core Materials
}

\author{
ANDREI - DANIEL VOICU ${ }^{1,2}$, ANTON HADAR ${ }^{1,3,4}$, DANIEL VLASCEANU ${ }^{1}$, \\ DANIELA IOANA TUDOSE ${ }^{1 *}$ \\ ${ }^{1}$ University Politehnica of Bucharest, 313 Splaiul Independenței, 060042, Bucharest, Romania \\ ${ }^{2}$ Romanian Air Force, 1 Zborului Str., 719463, Otopeni, Romania \\ ${ }^{3}$ Academy of Romanian Scientists, 54 Splaiul Independenței, 050094, Bucharest, Romania \\ ${ }^{4}$ Technical Sciences Academy of Romania, 26 Dacia Blvd., 010413, Bucharest, Romania
}

\begin{abstract}
Determining the dynamic properties in the frequency domain of aircraft structural elements is a very important aspect taken into account nowadays by aircraft manufacturers. One of the helicopters most exposed element to structural vibrations is the rotor blade, thus making its construction and the material choice a very important decision. Finite element methods can be used to assess the vibrational properties of such elements, in order to prove their airworthiness. The main objective of the article is to study how the use of different materials affects the structural behavior of the helicopter tail rotor blade, with regard to the frequencies at which these structures are prone to vibrate. The blade profile is the NACA0012 symmetric airfoil used on the IAR330 helicopter tail rotor blade and the main objective is to identify the best inner core material, while highlighting the importance of polymeric materials.
\end{abstract}

Keywords: helicopter tail rotor blade, composite materials, polymeric foams, vibrational study.

\section{Introduction}

The vibrational study of the helicopter tail rotor blade is one of the most important procedures that such a structure must undergo in order to be certified as airworthy and to be released into production. Thanks to the use of modern finite element simulation programs such as Ansys, the design and fabrication of these aeroelastic structures improved significantly.

The objective of modal analysis is to determine the dynamic characteristics of a structure, thus allowing researchers to study the natural frequencies and modal shape results. Understanding of the structural behavior of the helicopter tail rotor blade when exposed its eigenfrequencies is important in order to help maintain aircraft safety requirements at a high standard. Mass and rigidity are the two key parameters involved in the vibration analysis which can be varied within certain limits in order to achieve or avoid the appearance of resonance during flight conditions.

The main disadvantage of high vibration levels is the reduction of the fatigue life of certain structures, and when referring to the helicopter tail rotor blade, this can be a major issue because it is an essential element in ensuring the directional yaw control of the helicopter.

Important facts regarding the blade's aeroelastic and vibrational behaviour are presented by Bramwell et al. [1], such as the appereance of flutter (a dynamic instability of an aeroelastic structure which can develop uncontrollably and cause serious damage or even material failure) and the blade divergence (characterised by the surface deflection of the lifting surface under aerodynamic load in a direction which further increases lift in a positive feedback loop).

Ali DEMIRTAŞ et al. [2] describes a method of realising a modal analysis by considering an aircraft wing with a similar NACA airfoil as the tail rotor blade, as a cantilever beam, while ignoring the forces acting on the aircraft (except gravity). The results showed that the modal analysis validated the theoretical calculations in a certain amount, but unfortunately they where not validated experimentally. The metodology is promising and could be applied in the same matter on the helicopter tail rotor blade of the IAR330 helicopter, taking into account that the blade has a constant profile along it's lenght and is not geometrically twisted. 


\section{*email: daniela.tudor@upb.ro}

\section{Materials and methods}

The major structural components of the tail rotor blade of the IAR330 helicopter are, as presented in Figure 1: alloy;

-the spar - which runs across the entire length of the blade and is made from 6061-T6511 aluminium

-the honeycomb core - manufactured from 5052 aluminum alloy;

-the skin - profiled from the NACA0012 airfoil, made from 0,5 mm thick 6061-T4 aluminum alloy metal sheet.

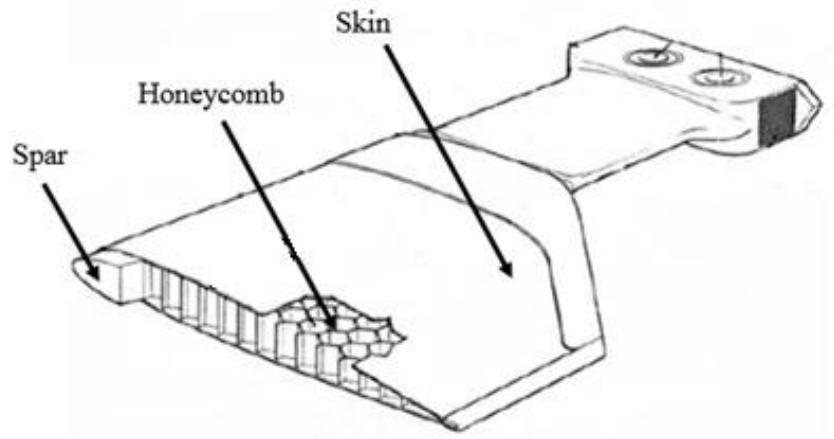

Figure 1. Main structural elements of the IAR330 helicopter tail rotor blade [6]

The main material properties of the IAR330 metal tail rotor blade components are presented in Table 1 .

Table 1. Material properties of the aluminum alloys used for the IAR330 tail rotor blade [3- 5]

\begin{tabular}{|c|c|c|c|}
\hline $\begin{array}{c}\text { Material } \\
\text { Property }\end{array}$ & $\begin{array}{c}\text { 6061-T6511 aluminum } \\
\text { alloy } \\
\text { (Spar) }\end{array}$ & $\begin{array}{c}5052 \text { aluminum alloy } \\
\text { (Honeycomb) }\end{array}$ & $\begin{array}{c}\text { 6061-T4 aluminum } \\
\text { alloy } \\
\text { (Skin) }\end{array}$ \\
\hline Density & $2700 \mathrm{~kg} / \mathrm{m}^{3}$ & $2680 \mathrm{~kg} / \mathrm{m}^{3}$ & $2700 \mathrm{~kg} / \mathrm{m}^{3}$ \\
\hline Ultimate Tensile Strength & $310 \mathrm{MPa}$ & $228 \mathrm{MPa}$ & $241 \mathrm{MPa}$ \\
\hline Tensile Yield Strength & $276 \mathrm{MPa}$ & $193 \mathrm{MPa}$ & $68.9 \mathrm{GPa}$ \\
\hline Modulus of Elasticity & $68.9 \mathrm{GPa}$ & $70.3 \mathrm{GPa}$ & 0.33 \\
\hline Poisson's Ratio & 0.33 & 0.33 & $96.5 \mathrm{MPa}$ \\
\hline Fatigue Strength & $96.5 \mathrm{MPa}$ & $117 \mathrm{MPa}$ & $26 \mathrm{GPa}$ \\
\hline Shear Modulus & $26 \mathrm{GPa}$ & $25.9 \mathrm{GPa}$ & $165 \mathrm{MPa}$ \\
\hline Shear Strength & $207 \mathrm{MPa}$ & $138 \mathrm{MPa}$ & \\
\hline
\end{tabular}

Taking into consideration the abundent development of composite and polymerie materials designed to satisfy requirements from various domains, the material selection for a composite tail rotor blade has to be realised with respect to the vibrational response of the structure.

The core of a composite laminate has the purpose of increasing the overall stiffness of the material by increasing it's thickness with a low-density material, resulting in little mass addition for the entire structure. The two main types of materials used in the composite tail rotor blades manufacturing are honeycomb or polymerie foam cores. Polymeric foams present the advantage of being easier to process in the desired shape and being commercialy available at a variety of densities, while honeycomb cores can be manufactured from a variety of materials, depending on the desired stiffness, with different shaped cells. Also, the cells of the honeycomb structure can be filled with a rigid foam.

A previous attempt to define structural behavior similarities between a honeycomb aluminium alloy core and a full metal core has been done for the IAR330 tail rotor blade model [6]. The finite element study concluded with a comparison of static structural numerical analysis results, highlighting the 
posibility of replacing the honeycomb core with a full inner core, in order to achieve a more convenient processing time for the numerical analysis, while determining similar results.

Kovalovs A. et al. realised a parametric study of a active twist rotor blade with a Rohacell 51 FX inner core [7], which is a closed-cell rigid foam plastic based on PMI (polymethacrylimide) often used in the construction of wind turbine blades and railcar structures.

Pascal F. et al. [8] and Rasuo [9] also utilized foam cores for similar helicopter blades in combination with skins of different thicknesses made from glass or carbon fiber reinforced plastics, leading to positive experimental results in terms of structural and impact behavior.

Also, Miller et al. [10] managed to realize a composite helicopter blade with embedded actuators for an active twist system, which achieved, during the experimental phase, a twist variation of $\pm 0.4^{\circ}$ at a cost of $16 \%$ weight increase. This was done for the UH-60A helicopter tail rotor blade, which also has a low-density polyurethane foam core in its construction inner structure.

Taking into account these examples and many others available in composite manufacturing and design industry [11], it is fair to say that for helicopter tail rotor blades, the main choice regarding the construction of their inner core is comprised of polymer foams.

In order to realize this study, the main types of aerospace polymer foams with similar properties, manufactured by different suppliers have been considered. The materials where selected in order to cover all the main types of polymer foams (polyurethane foam, PVC foam, PET Foam) and to determine which of them is more suitable for use in the structure of the tail rotor blade, from a vibrational point of view. Their main material properties are presented in Table 2.

Table 2. Main material properties of polymer foams used for aerospace applications

$\begin{array}{ccccc}\begin{array}{c}\text { Blade core manufacturing } \\ \text { material }\end{array} & \begin{array}{c}\text { FR-6700 rigid } \\ \text { polyurethane foam } \\ {[11]}\end{array} & \begin{array}{c}\text { Rohacell 110 } \\ \text { Hero rigid } \\ \text { polyurethane } \\ \text { foam [12] }\end{array} & \begin{array}{c}\text { Divinycell HT } \\ 131 \text { IPN foam } \\ {[13]}\end{array} & \begin{array}{c}\text { Corelite PET } \\ \text { foam [14] }\end{array} \\ \text { Manufacturer } & \text { General Plastics } & \text { Evonik } & \text { Diab Group } & \text { Corelite } \\ \text { Density }\left(\mathrm{kg} / \mathrm{m}^{3}\right) & 160 & 110 & 130 & 110 \\ \text { Compressive strength }(\mathrm{kPa}) & 2400 & 2500 & 3000 & 1630 \\ \text { Compressive Modulus }(\mathrm{kPa}) & - & 83000 & 170000 & 110000 \\ \text { Tensile strength }(\mathrm{kPa}) & 1950 & 6300 & 4800 & 2240 \\ \text { Tensile modulus }(\mathrm{kPa}) & - & 189000 & - & - \\ \text { Elongation at break }(\%) & - & 9.9 & - & 910 \\ \text { Shear strength }(\mathrm{kPa}) & 1550 & 2300 & 2200 & 30000 \\ \text { Shear modulus }(\mathrm{kPa}) & 75200 & 50000 & 50000 & 0.3 \\ \text { Poisson's ratio } & 0.3 & 0.3 & 0.3 & -\end{array}$

The FR-6700 polyurethane foam is an aerospace and military grade material manufactured by General Plastics Manufacturing Company, characterized by flame-retardant properties and a closed-cell structure which makes it highly resistant to water absorption. It has a high strength-to-weight ratio and a high stability and resistance to most chemicals and solvents. Also, this material can be easily processed thru the use of high-speed steel cutting tools water jets, and can be pre-scored for liquid infusion processes [12].

Realized by Evonik, the Rohacell brand has become a world-wide known solution for composite aircraft structures, particularly as an aircraft structural core material. The Rohacell Hero series has an entirely closed-cell structure and is known for its excellent mechanical properties and low density, which offers the most weight saving potential of all structural foams. Rohacell 110 Hero has good impact resistance, not allowing the deterioration to extend beyond the initial impact location and has a high elongation at break, which allows it to remain durable for the entire lifetime of the aircraft [13]. 
Divinycell HT is an aerospace closed-cell structural core produced by Diab Group which offers a very good strenght-to-weight ratio. It has a high processing temperature, which makes it conveniant for structural design in light aircraft, like private or bussines jet applications and it is also classified as selfextinguishing. It can be integrated in composite materials thru wet resin systems and infusions and it is even suitable for prepreg processing. The Divinycell HT 131 material is classified as a IPN foam (Inter Penetrating Network), representing a unique combination of cross linked polyurea and PVC [14].

The PET Foam core manufactured by Corelite is a closed-cell and cost-effective solution that can be chosen in order to provide high mechanical properties. Some of the main advantages of this material are its high mechanical resistance, homogenous cell structure and high temperature resistance and thermoformability. Also, it has been conceived to withstand high static and dynamic loads, presenting high fatigue resistance, chemical and UV resistance [15].

Overall, closed-cell foams are designed to offer better performances, being characterized by a higher rigidity and density than open-cell foams, making them more suitable for aerospace applications such as composite rotor blades.

The profiled section of the tail rotor blade model was realized in Ansys Workbench using the NACA0012 aerodynamic airfoil which has the following characteristics:

-symmetric shape along the chord line;

-maximum thickness located at $12 \%$ of its chord;

-entire blade has a length of approximately $1244.3 \mathrm{~mm}$

-the length of the chord of the airfoil measures approximately $185.5 \mathrm{~mm}$;

-the total mass of the blade as stated by the manufacturer is approximately $2.680 \mathrm{~kg}$.

In Figure 2 for comparison purpose only, the designed model of the metal IAR330 blade is presented as it was realized in the finite element software.

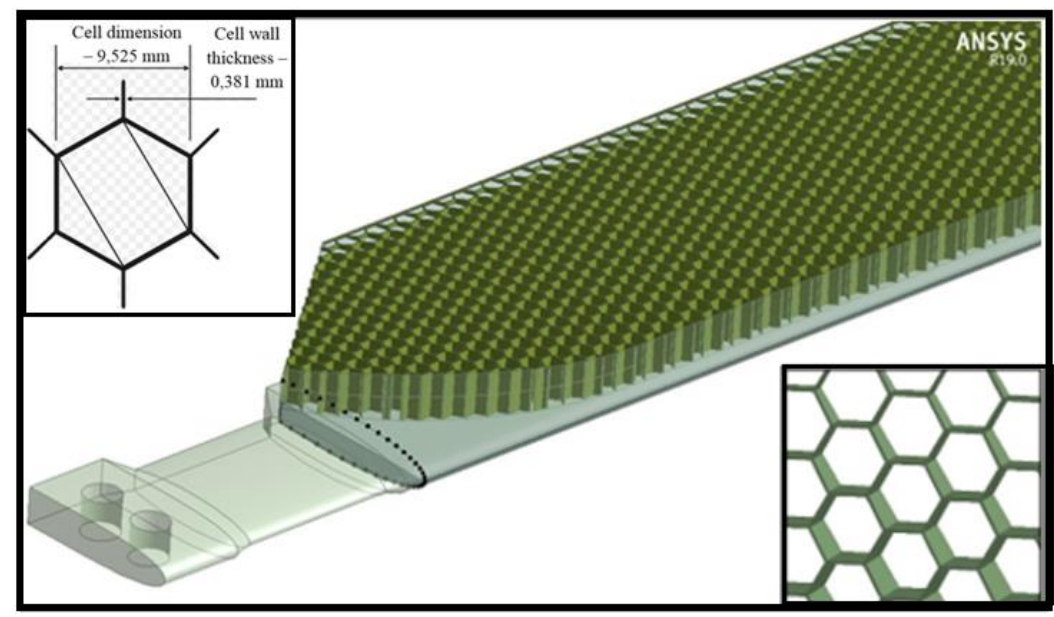

Figure 2. Structure of the metal IAR330 tail rotor blade [6]

In Figure 3 the structure of proposed composite version of the IAR330 tail rotor blade helicopter is shown, which will be subjected to the modal analysis in four different scenarios, according to the foam type used to fill the blade. 


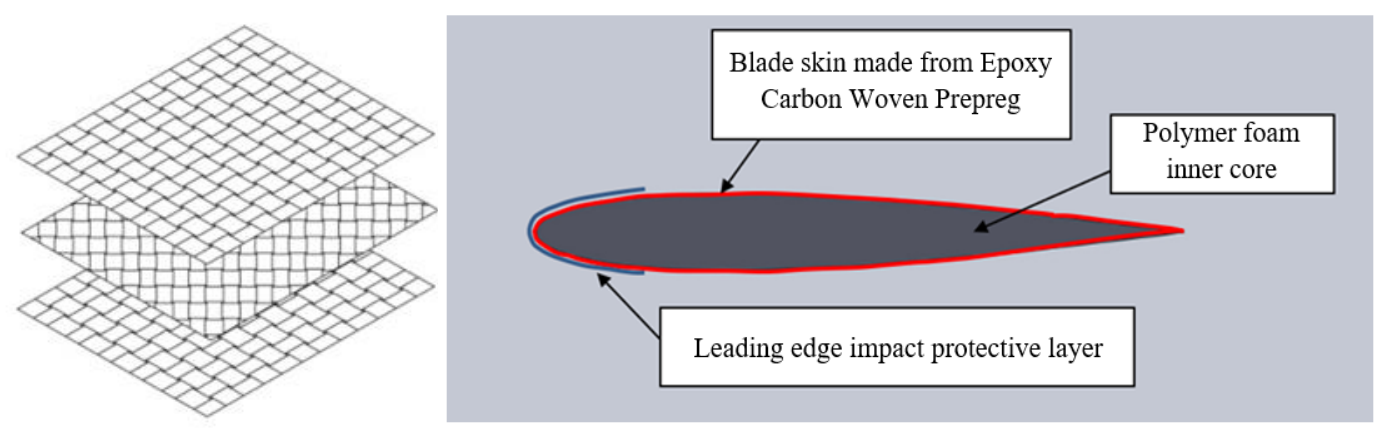

Figure 3. The proposed composite version of the IAR330 tail rotor blade

The skin of the composite blade is realized from a layup of six epoxy carbon woven prepregs, positioned at the following orientations (from bottom to top): $0^{\circ} / 90^{\circ} / 445^{\circ} /-45^{\circ} / 0^{\circ} / 90^{\circ}$, while the leading edge reinforcement is made from a layup of two laminas, with the following orientations: $0^{\circ} / 90^{\circ}$. The relatively simple structure of the composite tail rotor blade is justified by the desire of practically realizing and analyzing such a blade, in terms of its structural and vibration response. The laminas and the skin discretization which is realized from shell elements can be visualized in Figure 4 .

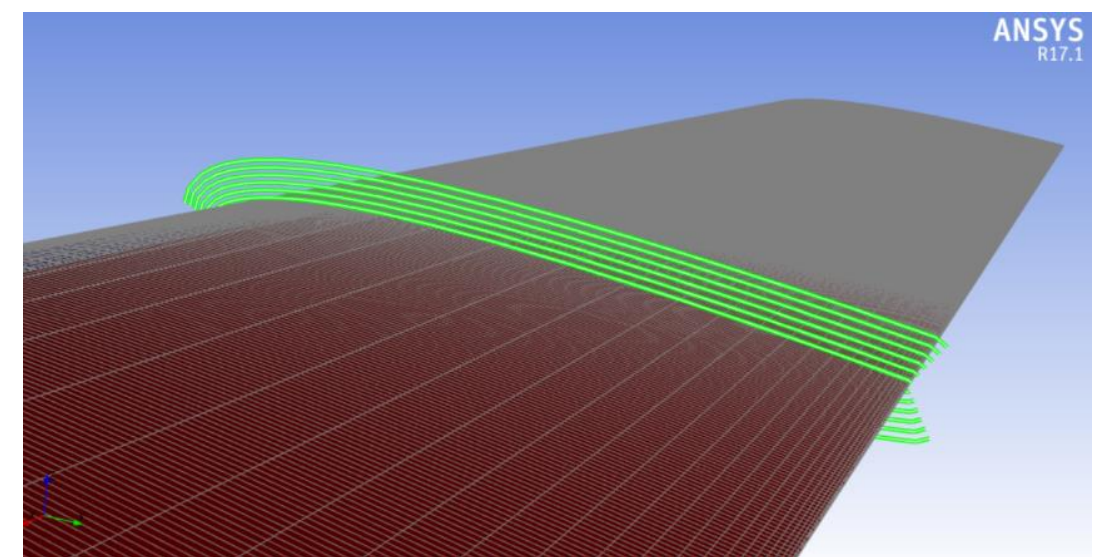

Figure 4. Discretization of the blade skin and visualization of the laminas layup

\section{Results and discussions}

The numerical analysis was realized using Ansys Workbench with the constrained on one side and with all six degrees of freedom available on the other side, with the purpose of determining the natural frequencies and mode shape results for the first ten vibration modes.

The solver determines the solution while considering the system undamped and with no pre-stresses taken into account. The natural frequencies obtained by the solver are presented in Table 3 for each version of the tail rotor blade and are exposed graphically in Figure 5.

Table 3. Comparison of the natural frequencies obtained from the numerical analysis for the first ten free vibration modes

\begin{tabular}{|c|c|c|c|c|}
\hline $\begin{array}{l}\text { Inner core } \\
\text { material }\end{array}$ & $\begin{array}{r}\text { FR-6700 rigid } \\
\text { polyurethane foam }\end{array}$ & $\begin{array}{c}\text { Rohacell } 110 \\
\text { Hero rigid } \\
\text { polyurethane foam }\end{array}$ & $\begin{array}{l}\text { Divinycell HT } \\
131 \text { IPN foam }\end{array}$ & $\begin{array}{l}\text { Corelite PET } \\
\text { foam }\end{array}$ \\
\hline Mode 1 & 23.92 & 30.793 & 23.776 & 46.235 \\
\hline Mode 2 & 110.69 & 139.83 & 109.35 & 167.91 \\
\hline Mode 3 & 120.22 & 147.29 & 121.08 & 196.21 \\
\hline Mode 4 & 185.98 & 229.4 & 185.06 & 343.6 \\
\hline
\end{tabular}




\begin{tabular}{|c|c|c|c|c|}
\hline Mode 5 & 279.89 & 347.4 & 281.37 & 477.33 \\
\hline Mode 6 & 414.34 & 480.81 & 415.84 & 646.92 \\
\hline Mode 7 & 454.59 & 588.76 & 453.21 & 850.2 \\
\hline Mode 8 & 614.85 & 724.06 & 610.06 & 861.91 \\
\hline Mode 9 & 641.69 & 771.97 & 644.83 & 1030.7 \\
\hline Mode 10 & 666.21 & 843.28 & 673.87 & 1309.3 \\
\hline
\end{tabular}

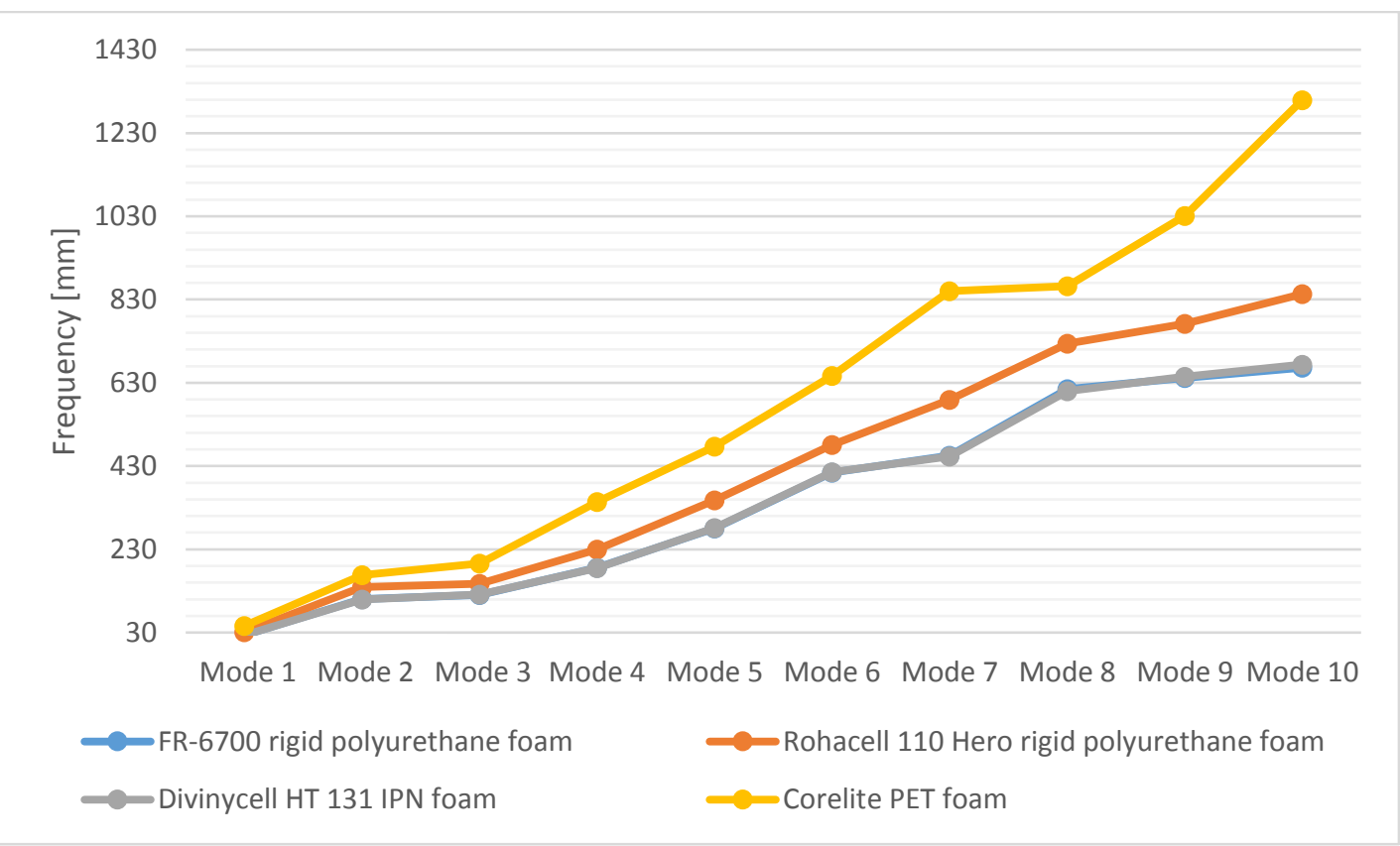

Figure 5. Natural frequency variation for the first ten free vibration modes

Judging by the previous figure, it is clear that the Corelite PET foam offers the maximum rigidity of all four core types, while maintaining the blade mass at a minimum. Starting with the second vibration mode, it can be seen that with each natural mode the frequency difference between the PET foam and other foams increases.

Although relative as values, the maximum total deformations for the blade with all four different core types are presented in Table 4 and can be graphically visualized in figure 6 , in order to facilitate a more adequate comparison.

Table 4. Comparison of the deformations obtained from the numerical analysis for the first ten free vibration modes

\begin{tabular}{|c|c|c|c|c|}
\hline $\begin{array}{c}\text { Maximum Inner core } \\
\text { total deformation } \\
\text { of the blade }\end{array}$ & $\begin{array}{c}\text { FR-6700 rigid } \\
\text { polyurethane foam } \\
{[\mathrm{mm}]}\end{array}$ & $\begin{array}{c}\text { Rohacell 110 Hero } \\
\text { rigid polyurethane } \\
\text { foam [mm] }\end{array}$ & $\begin{array}{c}\text { Divinycell HT 131 } \\
\text { IPN foam [mm] }\end{array}$ & $\begin{array}{c}\text { Corelite PET } \\
\text { foam [mm] }\end{array}$ \\
\hline Mode 1 & 45.932 & 50.051 & 47.233 & 50.985 \\
\hline Mode 2 & 47.455 & 51.779 & 48.688 & 52.987 \\
\hline Mode 3 & 48.395 & 51.982 & 49.957 & 56.513 \\
\hline Mode 4 & 71.176 & 73.444 & 72.483 & 68.206 \\
\hline Mode 5 & 47.596 & 51.515 & 49.339 & 58.858 \\
\hline Mode 6 & 64.669 & 77.263 & 64.326 & 74.227 \\
\hline Mode 7 & 51.781 & 56.676 & 54.349 & 50.847 \\
\hline Mode 8 & 55.216 & 52.869 & 55.768 & 55.926 \\
\hline Mode 9 & 66.006 & 73.347 & 67.832 & 82.898 \\
\hline Mode 10 & 56.716 & 61.235 & 55.042 & 78.885 \\
\hline
\end{tabular}




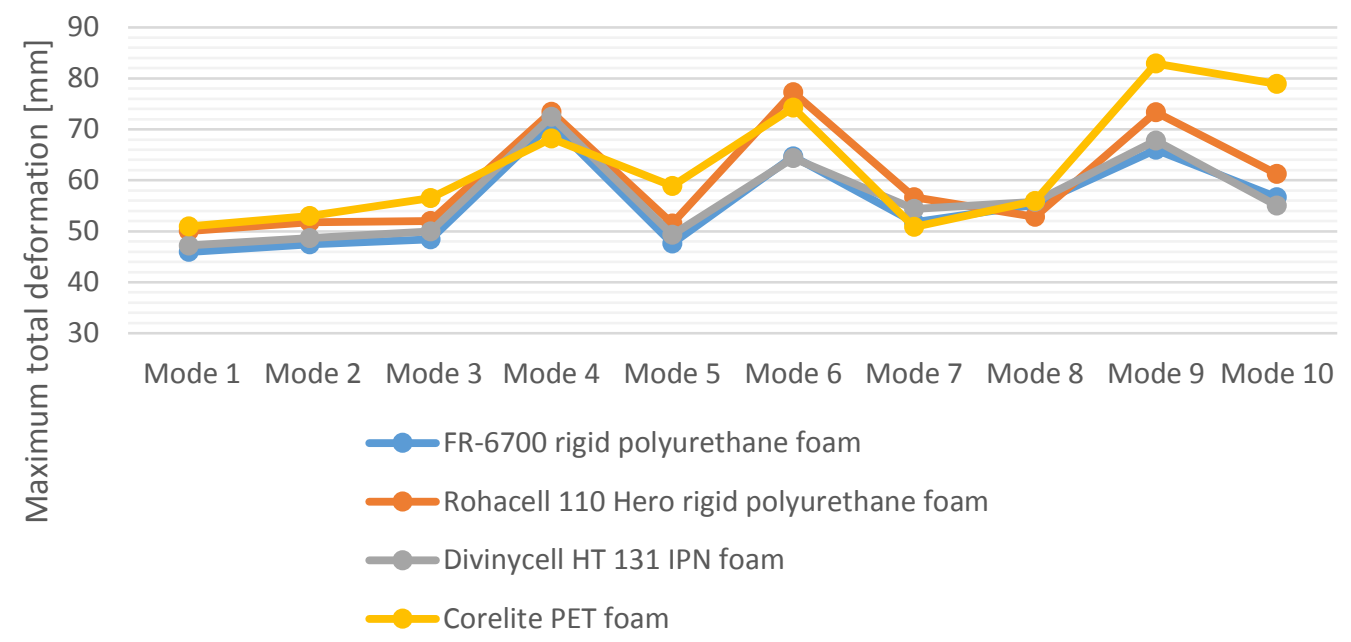

Figure 6. Maximum total deformation variation for the first ten free vibration modes

According to the previous chart, it can be stated that the smallest maximum deformation values are obtained for the FR6700 and Divinycell HT 131 IPN foams, while the highest values are obtained for the other two foam types, with the maximum overall value corresponding to the Corelite PET foam number nine vibration mode. Taking into account the frequency values presented in figure number 5, it can be deduced that Corelite PET foam, followed by Rohacel 110 Hero polyurethane foam, offer a higher rigidity to the blade structure, with the cost of an increase in the amplitude of the maximum total deformation of the blade.

The static pressure generated by the aerodynamic forces acting on the helicopter tail rotor blade, were determined by using Fluent Flow and they represent a pre-stress condition which will be applied on the blade, in order to verify how this imposed load affects the vibration behavior of the composite structure. Also, the Fluent Flow pressure values were validated in a previous article [16] by placing the tail rotor blade inside a subsonic wind tunnel and reading the values sensed by the pressure ports embedded in the blade.

Previous studies have been realized concluding that properly tuned stresses can reduce vibration amplitudes in certain locations, but might induce an increase in vibration amplitude in another location on the structure [17]. It is therefore interesting to compare the structural response of the pre-stressed structure with the response of the free structure and to determine if the forced vibrations imposed on the blade surpass the natural vibration characteristics.

The static structural load generated by the rotational velocity of $1278 \mathrm{rpm}(133.83 \mathrm{rad} / \mathrm{s})$ was applied on the body of the blade, corresponding to the normal rotation speed of the IAR330 tail rotor assembly. The comparative results between the blade with and without pre-stress are presented in Table 5 for the first six vibration modes previously discussed.

Table 5. Comparison of vibration modes for the tail rotor blade with and without pre-stress

\begin{tabular}{|c|c|c|c|c|c|}
\hline \multicolumn{2}{|c|}{$\begin{array}{c}\text { Inner core } \\
\text { material }\end{array}$} & $\begin{array}{c}\text { FR-6700 rigid } \\
\text { polyurethane } \\
\text { foam }[\mathrm{Hz}]\end{array}$ & $\begin{array}{c}\text { Rohacell 110 Hero } \\
\text { rigid polyurethane } \\
\text { foam [Hz] }\end{array}$ & $\begin{array}{c}\text { Divinycell HT } \\
\text { 131 IPN foam } \\
{\left[\begin{array}{c}\text { Frequency results } \\
\text { foam }\end{array}\right.}\end{array}$ & $\begin{array}{c}\text { Corelite PET } \\
\text { foam [Hz] }\end{array}$ \\
\hline Without pre-stress & \multirow{2}{*}{ Mode 1 } & 23.92 & 30.793 & 23.776 & 46.235 \\
\cline { 4 - 6 } & & 19.956 & 23.871 & 20.327 & 34.57 \\
\hline With pre-stress & $\mathbf{1 6 . 5 7 \%}$ & $\mathbf{2 2 . 4 8 \%}$ & $\mathbf{1 4 . 5 1 \%}$ & $\mathbf{2 5 . 2 3 \%}$ \\
\hline $\begin{array}{c}\text { Frequency decrease with } \\
\text { pre-stress }\end{array}$ & \multirow{2}{*}{ Mode 2 } & 110.69 & 139.83 & 109.35 & 167.91 \\
\hline Without pre-stress & 58.669 & 87.949 & 57.286 & 148.81 \\
\hline With pre-stress & & & &
\end{tabular}




\begin{tabular}{|c|c|c|c|c|c|}
\hline $\begin{array}{l}\text { Frequency decrease with } \\
\text { pre-stress }\end{array}$ & & $47.00 \%$ & $37.10 \%$ & $47.61 \%$ & $11.38 \%$ \\
\hline Without pre-stress & \multirow{3}{*}{ Mode 3} & 120.22 & 147.29 & 121.08 & 196.21 \\
\hline With pre-stress & & 111.37 & 128.49 & 113.45 & 164.25 \\
\hline $\begin{array}{l}\text { Frequency decrease with } \\
\text { pre-stress }\end{array}$ & & $7.36 \%$ & $12.76 \%$ & $6.30 \%$ & $16.29 \%$ \\
\hline Without pre-stress & \multirow{3}{*}{ Mode 4} & 185.98 & 229.4 & 185.06 & 343.6 \\
\hline With pre-stress & & 151.03 & 184.11 & 150.55 & 261.03 \\
\hline $\begin{array}{l}\text { Frequency decrease with } \\
\text { pre-stress }\end{array}$ & & $18.79 \%$ & $19.74 \%$ & $18.65 \%$ & $24.03 \%$ \\
\hline Without pre-stress & \multirow{3}{*}{ Mode 5} & 279.89 & 347.4 & 281.37 & 477.33 \\
\hline With pre-stress & & 267.99 & 327.07 & 269.94 & 426.8 \\
\hline $\begin{array}{c}\text { Frequency decrease with } \\
\text { pre-stress }\end{array}$ & & $4.25 \%$ & $5.85 \%$ & $4.06 \%$ & $10.59 \%$ \\
\hline Without pre-stress & \multirow{3}{*}{ Mode 6} & 414.34 & 480.81 & 415.84 & 646.92 \\
\hline With pre-stress & & 369.06 & 432.34 & 370.2 & 577.21 \\
\hline $\begin{array}{c}\text { Frequency decrease with } \\
\text { pre-stress }\end{array}$ & & $10.93 \%$ & $10.08 \%$ & $10.98 \%$ & $10.78 \%$ \\
\hline
\end{tabular}

Due to the fact that the Corelite PET foam offers better results in terms of natural frequencies and deflections, the mode shape results for all the ten vibration modes of the blade which incorporate this material are presented in Figure 7.
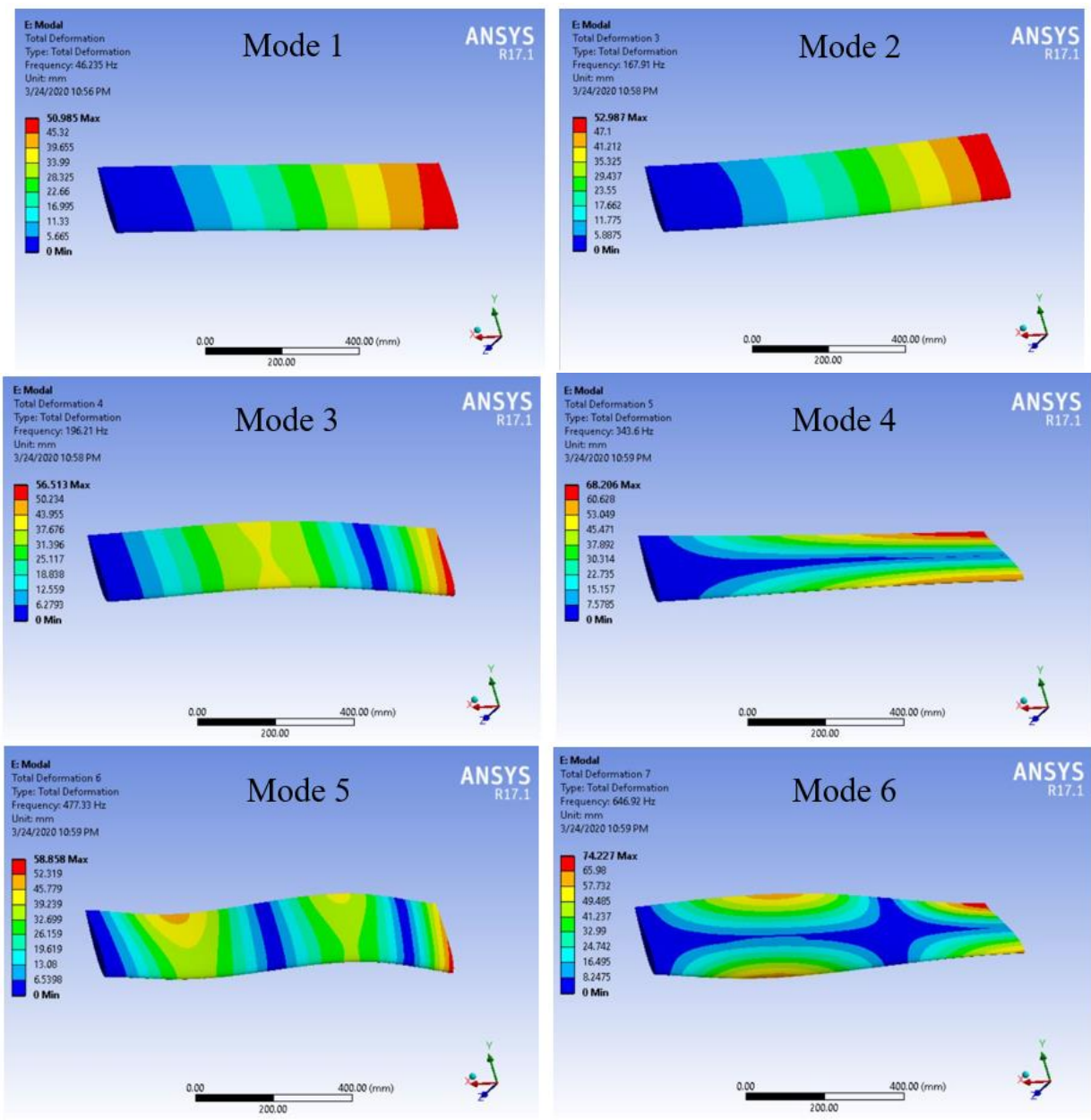


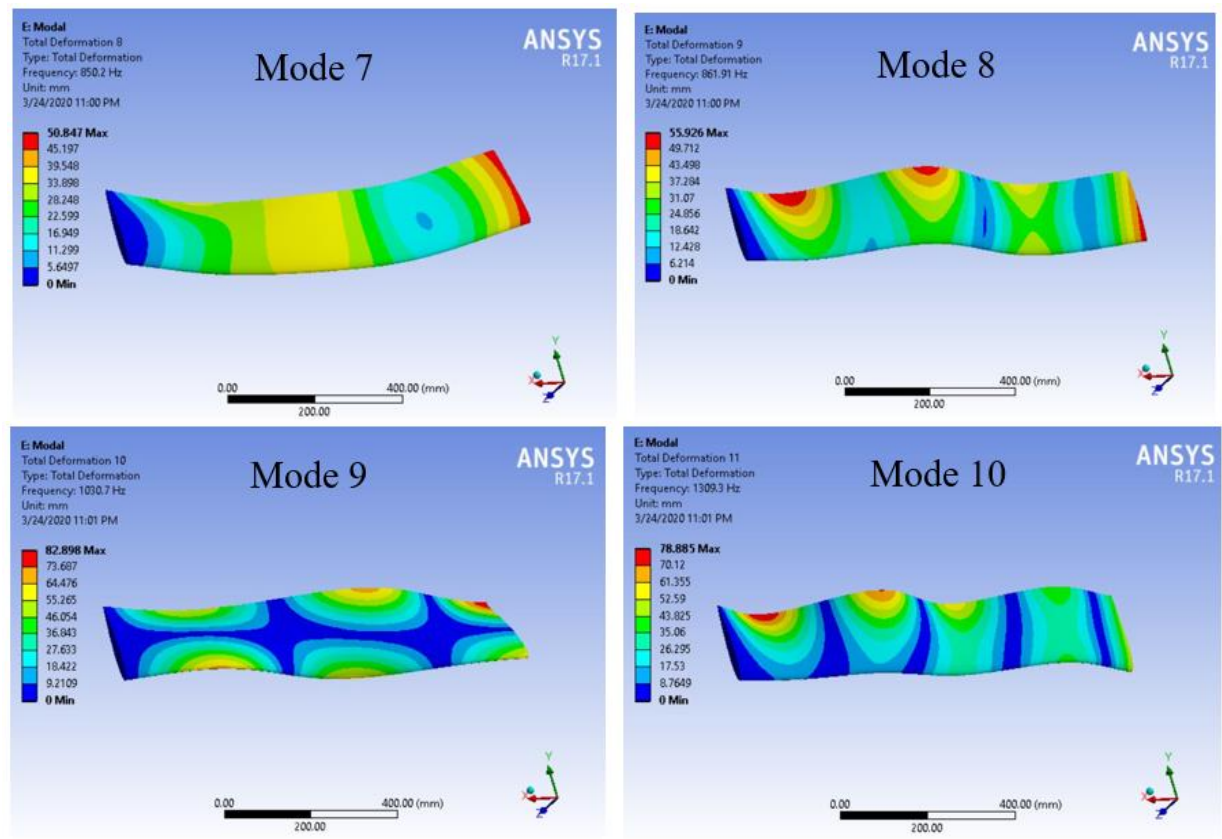

Figure 7. The shape results for the first ten free vibration modes of the composite tail rotor blade with the Corelite PET inner core

The vibrational behavior of the tail rotor blade is comprised of a ten total mode shape results, out of which two are simple bending modes (Modes 1 and 2) with the maximum deflection located at the tip of the blade, three of them are multiple bending modes (Modes 3, 5, 7), one is a torsional mode (Mode 4) with the torsion tacking place at the tip of the blade and spanning across the longitudinal axis and four of them are coupled bending-torsion modes (Modes 6, 8, 9,10). As Figure 7 indicates the natural frequency span is between $46.235 \div 1309.30 \mathrm{~Hz}$ for the stress-free blade. Introducing the pre-stress effect on the tail rotor blade thru the use of the rotational velocity induces a stiffening effect generated by the presence of the centrifugal force. The level of stiffening is dependent on several factors such as the rotational velocity of the blade, the blade length and the incidence angle made by the blade chord and the rotation direction, which in the end reflects on the reduction of the natural frequencies' values.

\section{Conclusions}

Polymer foams represent a simple and efficient solution of realizing aerospace sandwich structures with proper mass and rigidity. There are numerous manufacturers of such materials, offering products that meet even the strictest requirements in terms of structural resistance, aeroelasticity and resistance to chemical and environmental factors. The tail rotor blade represents the structural components which modifies the traction of the tail rotor assembly, being subjected to numerous aerodynamic and environmental loads. Therefore, with the purpose of realizing a composite tail rotor blade for the IAR330 helicopter currently used by the Romanian Air Force, the vibrational behavior of the blade has been study in different scenarios. A selection of commercially available structural aerospace foams has been presented and subjected to the modal analysis (with and without aerodynamical pre-stress), with the purpose of determining which of these materials offer better performances.

The numerical analysis results suggest, in terms of increasing the natural frequencies, that the Corelite PET foam offers the optimal solution, with the cost of an increase in the amplitude of the maximum total deformation. Also, taking into account that it has the lowest density, along with the Rohacell 110 foam, implementing it in the tail rotor blade structure, along with a six-layer carbon fiber weave impregnated with epoxy resin, offers a significant mass reduction of approximately $36.5 \%$ in comparison to the initial metal blade. 
Also, the stiffening effect generated by the blade rotation has been discussed and the results indicated than the presence of the centrifugal force on the rotating blade is responsible for a mean frequency reduction of approximately $17 \%$ for all previously discussed materials, in comparison with the natural frequencies of the blade without pre-stress.

In conclusion, the polymer foam structure of the tail rotor blade offers a higher degree of rigidity and if practically realized, enhances the performance of the entire IAR330 helicopter.

Acknowledgements. This work is supported by the project ANTREPRENORDOC, in the framework of Human Resources Development Operational Programme 2014-2020, financed from the European Social Fund under the contract number 36355/23.05.2019 HRD OP /380/6/13 - SMIS Code: 123847.

\section{References}

1. BRAMWELL, A. R. S., DONE, G., BALMFORD, D., Bramwell's Helicopter Dynamics, Elsevier Butterworth-Heinemann, 2001.

2. BAYRAKTAR, M., DEMIRTAȘ, A., Free vibration analysis of an aircraft wing by considering as a cantilever beam, Selcuk University Journal of Engineering, Science and Technology, p. 134-139, 2019. 3.*** http://asm.matweb.com/search/SpecificMaterial.asp?bassnum=ma6061t4.

4.***http://asm.matweb.com/search/SpecificMaterial.asp?bassnum=ma6061t6

5.***http://www.ct-sim.eu/honeycombcore/nida-aluminum-honeycomb-technical-doc-v06-en.pdf.

6. VOICU, A. D., HADĂR, A., VLĂSCEANU, D., Improving the mechanical behavior of a helicopter tail rotor blade through the use of polyurethane foams, Revista de chimie, 70 (11), p. 4123-4127, 2019.

7. KOVALOVS, A., BARKANOV, E., RUCHEVSKIS, S., WESELOWSKI, M., Optimisation Methodology of a Full-Scale Active Twist Rotor Blade, $16^{\text {th }}$ Conference on Reliability and Statistics in Transportation and Communication, RelStat'2016, 19-22 October, 2016, Riga, Latvia.

8. PASCAL, F., NAVARRO, P., MARGUET, S., FERRERO, J.-F., AUBRY, J., LEMAIRE, S., Study of medium velocity impacts on the lower surface of helicopter blade, Procedia Engineering, 88, p. 93$100,2014$.

9. RASUO, B., Full-Scale Fatigue Testing of the Helicopter Blades from Composite Laminated Materials in the Development Process, Journal of the Mechanical Behavior of Materials, 19 (5), 2009.

10. MILLER, M., NARKIEWICZ, J., KANIA, W., CZECHYRA, T., The application of helicopter rotor blade active control systems for noise and vibration reduction performance, Materials Science, p. 164180, 2006.

11. TABACU, ŞT., TABACU, I., HADĂR, A., Computational modelling of vehicle interior components for impact applications: thickness analysis", International Journal of Crashworthiness, 16 (4), p. 421 438, 2011.

12.*** https://www.generalplastics.com/products/fr-6700.

13.***https://www.rohacell.com/product/peekindustrial/downloads/rohacell\%20hero_2020,january.pd f.

14.***http://www.diabgroup.com/en-GB/Products-and-services/Core-Material/Divinycell-HT.

15.***https://www.corelitecomposites.com/corelite-pet\%C2\%AE2\#CoreLite\%20PET.

16. VOICU, A. D., HADĂR, A., VLĂSCEANU, D., Validation of a numerical fluid flow analysis for a helicopter tail rotor blade using a subsonic wind tunnel, 2019, Macromolecular Symposia Journal, Vol. 389, Issue 1, February 2020, https://doi.org/10.1002/masy.201900099.

17. SUWAŁA G., KNAP L., HOLNICKI-SZULC J., Prestressing for Reduction of Local Vibrations in a Rotorcraft, Engineering Transactions, 64, 3, pp. 367-380, 2016.

$\overline{\text { Manuscript received: } 4.06 .2020}$ 